\title{
Satu Dekade Pasca Invasi AS di Irak
}

\section{Budi Winarno}

Jurusan Hubungan Internasional, Fakultas IImu Sosial dan IImu Politik, Universitas Gadjah Mada Kampus Bulaksumur, Yogyakarta, 55281

Email:winarno@ugm.ac.id

\begin{abstract}
The main reasoning behind the United States' attack on Iraq, March, $20^{\text {th }} 2003$ among others was a geopolitics factor in the context of keeping oil supply safely. Therefore, it has influenced how the United States implementing the process of democaratization in Iraq. Although a new government of Iraq has been established through a general election supervised by the US, security and peace are still far away. In the contrary, Iraq has been plunged into a civil war. The traditional Israeli-American relation has been a key factor to keep American vital interest in Middle East. However, the instability of Iraq, has been crucial in influencing the democratization and peace in Iraq, as well as peace and security in Middle East.

Key words: US interest in Iraq and Middle East, democratization, security, and peace in Iraq and the Middle East.
\end{abstract}

\begin{abstract}
Abstrak
Alasan mendasar dibalik penyerangan Amerika Serikat terhadap Irak pada 20 Maret 2013 adalah faktor geopolitik dalam upaya menjaga keamanan suplai minyak. Oleh karena itu, hal ini mempengaruhi bagaimana kemudian Amerika Serikat melaksanakan proses demokratisasi di Irak. Meskipun pemerintahan baru Irak telah dibentuk melalui sebuah pemilihan umum yang juga diawasi oleh Amerika Serikat, keamanan dan perdamaian masih terlampau jauh. Sebaliknya, Irak telah terlibat dalam perang saudara. Hubungan tradisional Israel-Amerika menjadi faktor kunci untuk menjaga kepentingan vital Amerika di Timur Tengah. Bagaimanapun, instabilitas di Irak sudah krusial dalam mempengaruhi demokratisasi dan perdamaian di Irak, serta perdamaian dan kemanan di Timur Tengah.

Kata Kunci: Kepentingan Amerika di Irak dan Asia Tengah, demokratisasi, keamanan, dan perdamaian di Irak dan Asia Tengah.
\end{abstract}

\section{PENDAHULUAN}

Setelah mengalami kontroversi dan perdebatan yang panjang akhirnya Amerika Serikat (AS) memutuskan untuk melakukan serangan militer terhadap Irak. Invasi yang dimulai tanggal 20 Maret 2003, lebih dari sepuluh yang lalu hingga kini masih menyisakan persoalan. Pertama, menyangkut aspek legalitas serangan AS tersebut ke Irak. Banyak pengamat menilai bahwa invasi yang dilakukan oleh AS tidak sah, dan karenanya dapat dikategorikan sebagai suatu bentuk invasi ataupun penjajahan (kolonialisme).
Penunjukan Paul D Bremer sebagai administrator di Irak dapat dianggap sebagai suatu model pemerintahan kolonial. Selain itu, adalah tidak dibenarkan, suatu negara dengan alasan apapun menyingkirkan suatu pemimpin negara lain dengan menggunakan angkatan perang meskipun pemimpin tersebut otoriter dan despotis. Ini karena warga negara dari bangsa tersebutlah yang lebih mempunyai hak untuk menurunkan pemimpin mereka dari tampuk pemerintahan. Di sisi yang lain, invasi itu juga tidak 
mendapatkan legitimasi dari DK PBB setelah usahausaha yang dilakukan AS untuk mendapatkan dukungan di badan internasional tersebut tidak mendapatkan hasil. Sebagian besar negara-negara besar di DK PBB menolak rencana invasi tersebut, dan mereka menyarankan agar permasalahan Irak diselesaikan dengan jalan damai untuk menghindari bencana kemanusiaan. Ini sebagaimana diungkapkan oleh Menlu Jerman, Joschka Fischer yang negaranya memimpin DK PBB saat itu,"tugas kami adalah melakukan segala sesuatu yang dapat kami lakukan untuk menghindari bencana kemanusiaan." ${ }^{1}$. Namun pada akhirnya, dengan tanpa dukungan DK PBB, AS tetap melancarkan invasi ke Irak.

Kedua, masalah berikutnya yang sering mendapatkan perhatian dan dengan demikian menimbulkan diskusi di kalangan pengamat adalah menyangkut motivasi AS melakukan invasi ke Irak. Kuatnya keinginan George Walker Bush untuk menginvasi Irak dan menurunkan Saddam Husein dari tampuk pemerintahan dengan tanpa dukungan DK PBB telah menimbulkan spekulasi menyangkut motivasi AS di belakang aksi tersebut. Dalam diskusi panel yang diselenggarakan oleh The Middle East Policy Council (MEPC) pada tanggal 20 Juni 2003 di Washington DC, Presiden MEPC, Chas Freeman, menyatakan bahwa setidaknya ada enam alasan George W Bush melakukan invasi ke Irak, yakni²: Pertama, penghancuran program senjata pemusnah massal (mass weapon destruction). Ini menjadi salah satu alasan yang paling sering dikatakan Bush untuk melakukan invasi atau lebih tepatnya agresi ${ }^{3}$ militer AS ke Irak. Program pengembangan senjata pemusnah massal Saddam Husein dianggap sebagai ancaman bagi AS dan dunia. Oleh karena itu, dalam rangka membongkar program pemusnah senjata massal tersebut satu-satunya jalan adalah dengan serangan militer karena Saddam dianggap tidak kooperatif dengan tim inspeksi PBB. Menurut interpretasi Bush, penggunaan kekuatan militer untuk menghancurkan program senjata massal tidak menyalahi hukum internasional. Ini karena hukum internasional membenarkan penggunaan kekerasan bersenjata dalam tiga hal, yaitu untuk pertahanan diri (self-defense), untuk pelaksanaan ketentuan Bab VII Piagam PBB (enforcement action), dan walaupun masih diperdebatkan, untuk intervensi kemanusiaan (humanitarian intervention) ${ }^{4}$.

Pengembangan senjata pemusnah massal Irak dianggap sebagai ancaman bagi AS dan karenanya harus dihancurkan berdasarkan interpretasi paradigma pertahanan baru, yakni pre-emptive self- defense.

Administrasi Bush mengklaim bahwa sebelum perang dimulai, Irak mempunyai sedikitnya 500 ton gas mustard dan gas saraf, 25.000 liter anthrax, dan 38.000 racun plotulinum, dan lusinan rudal scud yang dapat digunakan untuk mengirimkan bahanbahan tersebut ${ }^{5}$. Klaim Bush mengenai kepemilikan senjata pemusnah massal masih menimbulkan perdebatan di kalangan pengamat dan politikus. Bahkan, Perdana Menteri Inggris Tony Blair sebagai pendukung kuat invasi Bush ke Irak menuai kritik pedas dari dalam negerinya, dan kredibilitasnya menurun drastis.

Kedua, perubahan rejim. Saddam Husein dalam pandangan Presiden Bush dianggap sebagai pemimpin yang otoriter. Oleh karena itu, setelah berbagai usaha melalui kelompok oposisi, bahkan mungkin juga dengan operasi intelijen telah gagal menjatuhkan Saddam dari kekuasaannya, maka invasi militer menjadi satu-satunya jalan. Ketiga, demokratisasi. Operasi AS di Irak diberi nama Operation Iraqi Freedom. Ini berarti bahwa invasi AS itu ditujukan untuk membebaskan Irak dari rejim otoriter Saddam Husein. Dengan kata lain, invasi ini ditujukan untuk menciptakan pemerintahan yang demokratis pascaSaddam. Keempat, perbaikan kehidupan rakyat Irak. Setelah mengalami embargo ekonomi sejak kekalahannya dalam Perang Teluk tahun 1991, kehidupan masyarakat Irak semakin memprihatinkan. Oleh karena itu, dalam rangka membangun kembali Irak pasca-invasi dan dalam rangka memperbaiki kehidupan rakyat Irak, AS telah menyediakan dana sebesar 8 miliar dollar untuk pembangunan kembali Irak ${ }^{6}$. Kelima, menghancurkan kegiatan terorisme internasional. Keenam, transformasi wilayah Timur Tengah di bawah pengawasan AS. 
Sementara itu, M Solihat (2003) ${ }^{7}$ menyatakan bahwa setidaknya ada tiga hal yang mendorong AS melakukan invasi ke Irak. Pertama, kepentingan geopolitik AS di kawasan Timur Tengah. Untuk memperkuat pengaruhnya di kawasan yang kerap tidak stabil itu, AS membutuhkan teman, yang dalam hal ini diidentikkan dengan Israel, yang juga punya kepentingan sama. Oleh karena itu, AS selalu berupaya melindungi Israel dari ancaman negara-negara lain di Timur Tengah, khususnya Irak. Selama Perang Teluk berlangsung, setidaknya Israel telah beberapa kali menjadi sasaran dari rudal-rudal yang diluncurkan oleh Saddam, dan dalam konteks ini AS telah menjadi "dewa" penyelamat yang baik bagi Israel dengan menempatkan rudal-rudal Patriot di kawasan negara tersebut. Oleh karena itu, jika kekuatan Saddam dibiarkan terus berkembang, maka di masa yang akan datang akan membahayakan Israel, dan tentunya juga AS. Kedua, perang tersebut berkait dengan kepentingan minyak. AS hanya mempunyai cadangan minyak yang sangat kecil, yakni sekitar 0,3\% dari cadangan minyak dunia, sedangkan kebutuhan konsumsi minyak AS mencapai 23\%. Di sisi yang lain, Arab Saudi yang mempunyai cadangan minyak terbesar di dunia sudah mulai tidak akomodatif lagi terhadap kepentingan-kepentingan AS. Ini tentu saja akan mengancam pasokan energi AS di masa datang, dan akan mengganggu kinerja industrinya. Oleh karena itu, AS berusaha untuk mengamankan kepentingan minyaknya di kawasan ini. Kuatnya kepentingan AS untuk menguasai minyak di kawasan ini juga pernah dilontarkan oleh Chomsky dan Albert (1991) ketika Bush memaksa pasukan Saddam keluar dari Kuwait. Menurut mereka,

The real reason for U.S. opposition to Iraqi occupation of Kuwait is not to keep oil prices low, but to keep Washington, Wall Street, and their allies in charge of setting oil prices. We are fighting to maintain and even enlarge one of our few continuing claims to international economic clouts: control of oil prices ${ }^{8}$.

Ketiga, perang ini berhubungan dengan ambisi AS sebagai negara terkuat di dunia yang tidak ingin setiap kepentingannya dihambat oleh siapapun, termasuk sebuah rezim berkuasa. Oleh karena itu, segala hal yang menurut persepsi AS mengandung potensi ancaman akan selalu diberangusnya.

Sebenarnya motivasi di balik invasi AS ke Irak dapat diidentifikasi dengan baik jika kita mampu menganalisis perkembangan politik luar negeri pasca Perang Dingin, dan situasi dalam negeri AS. Kaufman, McKitrick dan Leney (1995) menyatakan bahwa politik luar negeri AS mempunyai banyak dimensi. Diantara dimensi-dimensi tersebut yang paling penting dan utama menurut mereka adalah dalam dimensi kebijakan politik/diplomasi, kebijakan ekonomi, dan militer dengan lebih menitikberatkan pada keamanan internasional. ${ }^{9}$ Kebijakan ini dapat dianggap sebagai grand strategy yang didasarkan pada kekuatan geopolitik dengan berbagai konfigurasinya, dan kemampuan berperang. Dampaknya, keamanan nasional AS ditentukan oleh superioritas relatif ekonomi dan teknologinya dibandingkan dengan potensi ekonomi dan teknologi musuh-musuhnya ${ }^{10}$. Oleh karena itu, suatu negara akan dianggap sebagai ancaman bagi AS jika negara tersebut mampu mengembangkan kemampuan ekonomi dan keunggulan industri, terutama industri militer. Tentunya, ini juga harus dilihat dalam konteks apakah negara tadi mendukung kepentingan $\mathrm{AS}^{11}$ ataukah tidak? Dalam banyak kasus, ketika suatu negara mendukung kepentingan AS maka yang dilakukan adalah sebaliknya, yakni mendorong perkembangan ekonomi dan industri negara-negara tersebut. Korea Selatan semasa Perang Dingin, dan Israel di kawasan Timur Tengah dapat dijadikan contoh untuk mendukung argumentasi ini. Dengan demikian, dapat dipahami mengapa AS sangat memusuhi Korea Utara, Iran, dan Irak. Ini karena dalam pemahaman para pejabat Gedung Putih, negara-negara tersebut mengembangkan sistem persenjataan yang bisa mengancam AS, di samping juga negara-negara ini sangat tidak akomodatif terhadap kepentingan AS di masing-masing kawasan. Menyebut ketiga negara ini sebagai "axis of evil" menjadi cermin dari implementasi kekhawatiran Amerika menyangkut perkembangan teknologi persenjataan di ketiga negara ini. 
Selain itu, keagresifan AS dalam memerangi negaranegara yang tidak mendukung kepentingan AS juga dapat dilihat dari perubahan paradigma yang dikembangkan dalam sistem pertahanan, yakni menyangkut paradigma pertahanan pre-emptive selfdefense sebagaimana telah disinggung di awal tulisan. Paradigma ini memberi landasan para pemimpin yang berada di Gedung Putih untuk menyerang negaranegara yang dianggap menjadi ancaman bagi AS. Jika pada masa Perang Dingin AS akan bersifat menunggu (defensive) terhadap ancaman dari luar, maka berdasarkan paradigma ini, sistem pertahanan AS akan lebih bersifat ofensif terhadap ancaman militer dari luar. Di samping juga perlu dipahami kondisi psikologis masyarakat AS pasca tragedi World Trade Center. Bagaimanapun peristiwa ini merupakan pukulan berat bagi AS sebagai negara adidaya. Oleh karena itu, berbagai upaya dilakukan untuk memerangi jaringan terorisme internasional. Combating internatioal terrorism menjadi agenda para pejabat gedung putih di Washigton DC. Dalam konteks ini, William K. Tabb menyatakan bahwa isu terorisme kini telah menjadi seperti halnya ketakutan kepada "komunis" di masa lampau, dan telah menjadi alat ideologis yang kuat untuk mempertahankan kepentingan imperialis. ${ }^{12}$ Selanjutnya menurut Tabb, isu ini telah menjadi alasan pemerintah AS untuk melakukan intervensi di manapun dan kapanpun, memaksakan kehendaknya atau untuk menginvasi suatu negara dan menggulingkan pemerintahannya.

Terakhir, seringkali terjadi bahwa kepentingan Amerika terancam oleh negara-negara yang tidak seideologi. Oleh karena itu, menyebarkan ideologi AS, yang dalam hal ini adalah demokrasi dan liberalisme ekonomi menjadi suatu kewajiban. Program ini telah dimulai sejak masa Perang Dingin, dan nampaknya terus berlangsung hingga saat ini. Dengan demikian, salah satu tujuan invasi AS untuk mendorong terjadinya proses demokratisasi di Irak dapat dilihat dalam konteks ini.

Perdebatan menyangkut motivasi di balik invasi AS ke Irak tidak akan diperpanjang dalam tulisan ini. Namun, sebagaimana judul tulisan ini maka saya akan berusaha untuk memfokuskannya pada prospek demokrasi di Irak. Meskipun hal ini tetap harus diberi catatan bahwa pembahasan mengenai demokratisasi pasca invasi akan menegasikan realitas invasi itu sendiri. Bagaimanapun, agresi militer AS ke Irak tetap harus dilihat sebagai pelanggaran kedaulatan negara bangsa, dan merupakan ancaman bagi demokrasi dan perdamaian itu sendiri di masa datang. Kondisi ini akan semakin parah jika dokrin pre-emptive self-defense terus dikembangkan oleh AS karena kategori ancaman dalam konteks ini menjadi sangat subyektif. Ini pada akhirnya akan membuka peluang bagi AS untuk memaksakan kepentingan domestik dan internasionalnya kepada negara-negara yang tidak akomodatif terhadap kepentingan AS dalam arti luas, dan kepentingan pemimpin-pemimpin AS dalam pengertian yang lebih sempit ${ }^{13}$. Sebagaimana ditegaskan oleh Tabb, pilihan AS pada ancaman dan penggunaan kekerasan tidak ada hubungannya dengan mempertahankan demokrasi atau hal-hal semacamnya, tetapi berkaitan erat dengan siapa yang bekerjasama dan siapa yang tidak bekerja sama ${ }^{14}$.

Selanjutnya, tulisan ini juga hendak melihat prospek perdamaian, khususnya di Irak, dan kawasan Timur Tengah pada umumnya pasca serangan AS terhadap Irak. Masalah Timur Tengah telah menarik perhatian para pengamat politik internasional dan para politikus selama beberapa dekade belakangan. Dalam konteks ini, pertanyaan yang layak diajukan adalah prospek perdamaian di kawasan ini setelah Irak di bawah Saddam berhasil ditaklukkan oleh Bush. Apakah keruntuhan Saddam akan menjadi pintu pembuka bagi perdamaian yang panjang di Timur Tengah dan Irak menjadi tumbal bagi perdamaian di kawasan ini sebagaimana pernah diungkapkan oleh Henry Kissinger ${ }^{15}$, ataukah justru sebaliknya? Invasi Amerika akan mendorong kekerasan dalam skala yang lebih luas, dan dengan demikian perdamaian yang diharapkan menjadi mimpi di siang hari?

\section{PROSPEK DEMOKRATISASI DI IRAK}

Invasi militer Bush ke Irak satu dekade yang lalu ditujukan untuk mendorong proses demokratisasi di 
negara itu, mengukuhkan pandangan sementara penulis bahwa seringkali terjadi usaha-usaha untuk membangun suatu sistem politik demokratis digunakan cara-cara yang justru tidak demokratis. Terlepas dari kontroversi yang menyangkut motivasi dan legalitas invasi militer tersebut ke Irak, peristiwa ini memunculkan sejumlah paradoks. Agresi militer ini ditujukan, sesuai dengan namanya Operation of Iraqi Freedom, adalah dalam rangka membebaskan rakyat Irak dari rejim Saddam Husein yang otoriter. Namun dalam kenyataannya cara seperti ini lebih lazim digunakan oleh para pemimpin otoriter dan fasis. Di negara-negara fasis dan otoriter seperti Orde Baru era Soeharto, kekerasan dan kekuatan militer digunakan untuk membungkam suara-suara kritis dalam masyarakat. Militer digunakan semata-mata untuk menjamin dan melanggengkan kekuasaan politik rezim. Oleh karena itu, ketika agresi militer digunakan untuk menumbangkan rejim yang otoriter dan despotis maka ia menjadi kontraproduktif. Ini penting diberi catatan karena seringkali terjadi demokrasi hanya dijadikan sebagai alat semata-mata untuk melanggengkan kepentingan tertentu. Dengan kata lain, usaha AS untuk mendorong proses demokratisasi di Irak khususnya, dan Timur Tengah dalam area yang lebih luas, bisa jadi tidak ditujukan untuk mendorong secara sungguh-sungguh kawasan tersebut menjadi wilayah demokratis yang menjunjung tinggi hak-hak asasi manusia, namun lebih dalam konteks bagaimana kepentingan AS di kawasan tersebut tidak terancam sebagaimana pernah ditegaskan Tabb.

Sikap AS terhadap peristiwa kudeta militer di Aljazair dapat dijadikan contoh untuk mendukung argumentasi ini. Kemenangan kelompok Islam garis keras di Aljazair harus mentah atau dibatalkan karena kudeta militer yang dilakukan pada tahun 1992. Dalam kasus ini, AS diam seribu bahasa dan tidak berbuat apapun untuk mengembalikan pemerintahan demokratis di negara ini. Sikap ini diambil karena kepentingan AS akan terancam jika Aljazair menjadi sebuah negara Islam. Ini tentu saja sangat berbeda dengan yang dilakukan AS di Myanmar berkenaan dengan tokoh pejuang demokrasi di negara ini, Aung
San Su Kyi. Demikian juga yang dilakukan Kongres AS untuk menghentikan bantuan militer ke Indonesia pasca pelanggaran-pelanggaran hak asasi manusia di Timor Timur dan Irian Jaya ${ }^{16}$.

Sementara itu, menurut catatan Thantowi bahwa berbagai pengalaman menyangkut usaha-usaha AS untuk menjatuhkan rejim diktator secara paksa, seperti Grenada, Panama, Haiti, dan Afganistan,

mengindikasikan kehidupan sosial-politik pasca-invasi tetap tidak mengalami peningkatan berarti ${ }^{17}$. Dengan kata lain, negara-negara tersebut sedikit sekali mengalami kemajuan dalam kehidupan demokrasi mereka. Untuk mendukung preposisi ini, Thantowi mengambil contoh Haiti setelah invasi AS tahun 1994. Pasca invasi AS, negara ini kembali tergelincir dalam patologi-patologi yang menandai kehidupan politik sebelum junta militer mengambil alih kekuasaan pada 1991. Contoh yang lain adalah Afganistan. Kehidupan sosial politik demokrasi di wilayah ini sejak Hamid Kharzai berkuasa juga tidak mengalami kemajuan yang berarti jika dibandingkan dengan masa pemerintahan Taliban.

Fakta-fakta ini sengaja ditampilkan dalam tulisan ini agar kita tidak terjebak pada harapan yang terlalu berlebihan terhadap peran AS dalam mendorong proses demokratisasi di Irak dan kawasan Timur Tengah. Karena meskipun AS akan membantu proses demokratisasi di wilayah ini, maka tetap tidak bisa dilepaskan dari kepentingan geopolitiknya. Sebaliknya, proses demokratisasi hendaknya lebih dilihat dalam konteks internal masing-masing negara, terutama menyangkut suprastruktur dan infrastruktur demokratis yang mendukungnya. Ini berarti bahwa meskipun pihak luar mempunyai peran dalam proses demokratisasi di Irak, namun peran ini tidak akan banyak berarti jika kondisi internal tidak mendukung proses tersebut. Salah satu faktor yang mempunyai peran besar dalam mendorong demokratisasi tersebut adalah budaya politik dan pembangunan ekonomi.

\section{PRAKONDISI BAGI PROSES DEMOKRATISASI}

Salah seorang ahli di bidang budaya politik dan nilai-nilai demokrasi, Ronald Inglehart ${ }^{18}$, melakukan 
survei terhadap tujuh puluh negara di dunia. Negaranegara yang dijadikan sampel mencakup negara-negara dengan sistem yang paling demokratis, seperti negaranegara demokrasi Eropa Barat dan negara-negara yang paling otoriter. Dari survei tersebut, Inglehart menyimpulkan bahwa untuk membangun demokrasi yang stabil dibutuhkan adanya budaya politik yang secara kuat mendukung demokrasi. Menurut Inglehart, faktor-faktor politik berikut ini mempunyai peran yang esensial, memainkan peran kolektif yang penting dalam mendorong dan mengukuhkan sistem demokrasi politik yang stabil. Faktor tersebut adalah:

- Kepercayaan politik (political trust), asumsinya adalah bahwa seorang lawan politik akan menerima aturan main dari proses demokrasi dan akan menyerahkan kekuasaannya jika ia kalah dalam pemilihan umum.

- Toleransi sosial (social tolerance), yang dimaksud dengan konsep ini adalah kerelaan untuk menerima kelompok-kelompok yang tidak populer dalam masyarakat, seperti kelompok homoseksual.

- Pembangunan ekonomi (standar hidup yang tinggi akan memberi legitimasi bagi institusi-intitusi demokrasi dan pemegang jabatan politik.

- Dukungan yang luas terhadap kesetaraan gender.

- Prioritas yang tinggi menyangkut kebebasan mengemukakan pendapat dan partisipasi massa rakyat dalam proses pengambilan keputusan.

Studi tersebut juga mencakup sepuluh negara muslim di dunia, dan menurut Inglehart, dalam masyarakat Islam, tingkat kepercayaan, toleransi, kondisi ekonomi, kesetaraan gender, dan prioritas yang diberikan untuk aktivitas politik jauh berada di bawah dari apa yang sering ditemukan di semua negara yang demokrasinya sudah mapan.

Kesimpulan Inglehart ini diperkuat oleh studi yang dilakukan oleh dua orang ilmuwan politik lainnya pada tahun 1990-an terhadap 131 negara di dunia. Menurut studi ini, pembangunan ekonomi menyebabkan nilai-nilai demokrasi berada pada tingkatan suatu budaya politik, yang pada gilirannya menghasilkan tingkatan demokrasi yang lebih stabil.
Dalam bahasa yang lebih ringkas, dapat dikatakan bahwa budaya politik akan menentukan demokrasi lebih daripada demokrasi menentukan budaya politik. Ini semakin menegaskan bahwa budaya politik suatu masyarakat negara bangsa akan sangat menentukan keberhasilan proses menuju transformasi menuju demokrasi.

Namun demikian, dalam konteks perkembangan demokrasi di negara-negara Islam, apa yang dikemukakan Inglehart di atas agak berbeda dengan analisis yang dilakukan oleh Markoff ${ }^{19}$. Sebagaimana dicatat oleh Markoff bahwa gerakan Islam di tahun 1990-an telah mulai melekatkan prosedur demokratis sebagai cara untuk mengelola kekuasaan. Ini dapat dilihat dalam proses pemilu di Aljazair, meskipun hasilnya, seperti telah disinggung di awal, dibatalkan dan diambil alih oleh militer melalui kudeta pada tahun 1992. Sementara itu, di negara-negara Islam yang lain angin demokrasi juga mulai menyeruak. Di Mesir dan Tunisia, gerakan Islam oposisi mulai mendesakkan dilakukannya pemilu yang kompetitif secara terbuka. Di Yordania, parlemen yang terbentuk merupakan hasil dari transformasi ini. Iran sebagai salah satu negara Islam yang tingkat militensinya besar juga cenderung mulai mengadopsi nilai-nilai demokratis. Ini tentunya merupakan perubahan yang menggembirakan bagi proses demokratisasi di wilayah tersebut, dan akan memberi lingkungan yang kondusif bagi Irak untuk menuju ke arah sistem yang lebih demokratis di masa datang. Namun di sisi yang lain, konflik yang terus meluas di kawasan ini, dan nampaknya masih akan terus berlanjut di masa datang, juga akan mempunyai pengaruh negatif terhadap perkembangan demokrasi di Irak.

Selanjutnya, dengan mendasarkan pada argumentasi Inglehart di atas, maka masa depan demokrasi di Irak setidaknya akan ditentukan oleh dua hal, yakni: Pertama, Budaya politik. Georg Sorensen mendefinisikan budaya politik sebagai sistem nilai dan keyakinan yang menjelaskan makna dan tindakan politik ${ }^{20}$. Dalam konteks ini maka yang menjadi pertanyaan adalah bagaimana budaya politik yang berkembang di Irak, sehingga budaya politik ini akan 
menjadi penopang yang kuat bagi proses demokrasi? Selama kurang lebih 20 tahun, oleh karena sifat pemerintahannya yang otoriter maka pendidikan politik sama sekali tidak terjadi. Akibatnya, sebagaimana proses demokrasi di Indonesia, masa depan demokrasi di Irak juga akan mengalami pasang surut. Selama pemerintahan Saddam, rakyat Irak hidup dalam kungkungan rejim yang tidak memberikan ruang bagi demokrasi, sehingga masyarakat tidak mempunyai kesempatan untuk belajar nilai-nilai demokrasi yang esensial. Akibatnya, usaha untuk membangun demokrasi yang stabil akan menjadi sangat sulit.

Akhirnya, tetap harus dipahami bahwa demokrasi adalah sesuatu yang harus diperjuangkan, bukan merupakan sesuatu yang diberikan oleh Tuhan (given). Untuk itu, diperlukan waktu yang lama sehingga nilainilai demokrasi yang diperjuangkan menginternal dalam suatu masyarakat. AS membutuhkan waktu lebih dari seratus tahun untuk menjadi seperti sekarang ini. Itupun masih diwarnai oleh praktikpraktik yang mengarah ke rasisme, terutama terhadap kaum minoritas. Oleh karena itu, harapan bahwa demokrasi akan lahir atau tercipta segera setelah Saddam dijatuhkan tidak mempunyai landasan empiris yang memadai dan cenderung naif. Demokrasi adalah sebuah proses, dan berhasil tidaknya proses tersebut akan sangat ditentukan oleh dialektika antar berbagai aktor yang terlibat dalam proses tersebut.

Kedua, pembangunan ekonomi. Kekalahan Irak dalam Perang Teluk tahun 1991 ternyata mempunyai implikasi yang sangat buruk terhadap rakyat Irak. Pemberlakuan embargo ekonomi oleh PBB telah membuat standar hidup rakyat Irak jatuh pada tingkatan yang sangat rendah. Pemberlakuan kebijakan yang mengijinkan Irak untuk menjual minyaknya guna kepentingan pangan dan obat-obatan dalam kenyataannya juga tidak banyak membantu rakyat Irak keluar dari kesulitan ekonomi. Sejak pemberlakuan Program Oil For Food Security Council Resolution 986 (UN-SC 986), membuat ekonomi Irak tidak memiliki purchasing power dalam perdagangan internasional. ${ }^{21}$ Untuk mengatasi hal ini, Irak melakukan perdagangan minyak ilegal dengan Rusia. Namun karena ketatnya pengawasan yang dilakukan oleh PBB membuat usaha-usaha tersebut gagal. Selama rentang waktu embargo tersebut, ribuan rakyat Irak telah mati sia-sia akibat penyakit radang paru-paru, pernafasan dan kekurangan gizi. Berdasarkan data yang diungkapkan oleh Departemen Kesehatan Irak, setidaknya kurang lebih 1.300.867 orang telah meninggal dunia hingga tahun 2000, dan 500 ribu diantaranya adalah anak-anak ${ }^{22}$. Banyak pihak mulai khawatir bahwa akibat kekurangan gizi pada anak-anak ini, Irak akan menderita the lost generation di masa yang akan datang.

Kondisi ini semakin diperparah oleh invasi AS dan Inggris di wilayah ini dalam rangka menggulingkan Saddam dari tampuk pemerintahan. Berbagai infrastruktur mengalami kerusakan, dan banyak diantara infrastruktur tersebut mengalami kerusakan berat akibat perang yang dilancarkan oleh pasukan AS dan Inggris. Berton-ton bom yang dijatuhkan di wilayah-wilayah Irak melalui pesawat-pesawat canggih AS telah meluluh lantakkan gedung-gedung sekolah, menghancurkan bangunan ibadah, rumah sakit dan kantor-kantor pemerintah. Masyarakat berada dalam kondisi kekurangan air, bahan makanan, dan obatobatan, dan penerangan (listrik). Dampaknya, masyarakat Irak berada dalam kesulitan hidup yang cukup tajam dan untuk melakukan perbaikan terhadap kondisi ini dibutuhkan waktu dan tenaga yang luar biasa besar hingga rakyat Irak dapat menikmati kembali kehidupannya seperti di masa sebelum Perang Teluk.

Kemiskinan atau dalam konteks ini, kesulitan hidup akibat perang dan embargo yang berkepanjangan telah membuat pelaksanaan demokrasi menjadi sulit. Setidaknya ini ditegaskan oleh Cohen sebagaimana kutipan berikut:

Ketika anggota masyarakat kekurangan gizi kronis dan sakit-sakitan, partisipasi dalam persoalan-persoalan umum baik yang luas maupun khusus, menjadi sulit dipertahankan. Ketika seringkali rakyat menderita kelaparan akut, atau ketika penyakit merajalela, harapan demokrasi sejati adalah naif. ${ }^{23}$ 
Meskipun perusahaan-perusahaan AS telah menandatangi kontrak untuk program pembangunan Irak pasca invasi, namun ini tetap membutuhkan waktu yang lama dan tidak mendapatkan dukungan dari rakyat Irak. Sebagaimana dicatat oleh Nick Beams, ${ }^{24}$ beberapa perusahaan besar AS telah menandatangi kontrak miliaran dollar untuk pembangunan Irak. Perusahaan-perusahaan tersebut diantaranya adalah Halliburton, yang menandatangani kontrak sebesar 7 miliyar dollar untuk memadamkan api dari kilang-kilang minyak yang terbakar, pengeboran, dan pendistribusian minyak Irak.; Kellogg, Brown dan Root, yang menandatangani kontrak sebesar 71 juta dollar untuk memperbaiki dan mengoperasikan sumur-sumur minyak; Bechtel, yang kini berencana menandatangani kontrak sebesar 34, 6 juta dollar dan mempunyai kemungkinan untuk naik hingga mencapai 680 juta dollar untuk membangun kembali sistem pembangkit energi dan sistem penyediaan air; MCI WorldCom, yang mempunyai kontrak sebesar 30 juta dollar untuk membangun jaringan tilpun di Irak; Stevedoring Services of America, yang menandatangani kontrak sebesar 4,8 juta dollar selama 1 tahun untuk mengelola dan memperbaiki pelabuhan-pelabuhan Irak, termasuk pelabuhan di Umm Qasr; ABT Associates, yang menandatangi kontrak sebesar 10 juta dollar untuk menyediakan dukungan bagi pelayanan kesehatan; Creative Associates International, yang menandatangi kontrak sebsar 1 juta dollar dan mungkin bisa naik mencapai 62,6 juta dollar untuk kebutuhan pendidikan dasar di Irak; dan lain sebagainya $\mathrm{a}^{25}$.

Akhirnya, persoalan-persoalan ekonomi yang kini menghimpit rakyat Irak menjadi fokus perhatian di masa-masa mendatang, dan ini juga menjadi prioritas siapa pun yang memegang kendali kekuasaan di Irak. Dengan demikian, jalan ke arah demokrasi masih menjadi tanda tanya besar di wilayah ini bila kondisikondisi ekonomi sebagai variabel yang menentukan pembangunan demokrasi dijadikan ukuran. Bahkan, kemungkinan terburuk dapat saja terjadi, yakni meluasnya kekerasan di wilayah Irak akibat kurangnya makan, tidak layaknya tempat tinggal, dan rendahnya kualitas kesehatan. Patologi sosial dalam bentuk anarkisme akan terjadi dimana-mana, dan ini pada akhirnya mendorong rejim yang berkuasa untuk melakukan tindakan-tindakan represif, termasuk AS. Kerusuhan-kerusuhan yang terjadi dalam beberapa waktu belakangan sebagaimana diakui administrator Paul D. Bremer sebagai akibat kelangkaan pasokan air, listrik dan bahan makanan menjadi contoh untuk hal ini. ${ }^{26}$ Oleh karena itu, menawarkan demokrasi di tengah kepahitan hidup akibat kesulitan ekonomi sebagaimana dialami rakyat Irak dewasa ini ibaratnya menawarkan batangan-batangan emas kepada nelayan yang hampir tenggelam di tengah lautan karena badai. Meskipun tawaran tersebut nampaknya indah, tetapi ada kebutuhan lain yang lebih mendesak, yakni hidup.

Ketiga, struktur sosial masyarakat. Sorensen menambahkan bahwa selain budaya politik dan pembangunan ekonomi, prakondisi penting lainnya bagi demokrasi adalah struktur sosial masyarakatnya. Sebagian besar, yakni sekitar 95\% rakyat Irak menganut agama Islam, dan sisanya adalah Kristen dan penganut agama lainnya. Deputi Perdana Menteri, Tariq Azziz, orang ke-4 dalam hirarki kepemimpinan Irak era Saddam Husein adalah pejabat tertinggi yang beragama Kristen.

Di sisi yang lain, Irak juga memiliki komposisi penduduk yang heterogen berdasarkan perbedaan suku, agama dan partai politik. Suku Arab, antara 75$80 \%$ merupakan populasi terbesar di Irak, disusul oleh Suku Kurdi, 15-20 \%, dan Suku Turkoman/ Asiria, $5 \%$. Dari komposisi heterogen tersebut memunculkan instabilitas politik dan keamanan di Irak karena telah terjadi pelepasan partisipasi politik dan ekonomi terhadap kelompok minoritas, khususnya Suku Kurdi dan Turkoman. Pembunuhan terhadap lawan politik dan pemberontakan bersenjata merupakan contoh nyata dari akibat pelepasan partisipasi politik dan ekonomi dari kaum minoritas ${ }^{27}$. Kondisi ini menjadi semakin parah karena desakan yang kuat dari Suku Kurdi untuk mendirikan negara sendiri dan menjadikan Kirkuk, sebagai wilayah penghasil minyak terbesar kedua, untuk dijadikan ibu 
kota negara. Selama pemerintahan Saddam, Suku Kurdi ini mendapatkan tekanan yang luar biasa, dan usaha untuk mendirikan negara sendiri lepas dari Irak nampaknya akan semakin kuat di masa-masa yang akan datang. Pada akhirnya, kondisi ini sangat mempengaruhi stabilitas di kawasan Irak dan kawasan Timur Tengah.

Rejim Saddam Husein dikuasai oleh muslim Sunni, sementara setengah dari penduduk Irak adalah penganut Islam Syiah. Inilah yang mendorong ASInggris tertarik untuk menggunakan kelompok ini guna menjatuhkan rejim Saddam Husein, meskipun pada akhirnya gagal. Selama pemerintahan Saddam Husein, muslim Syiah tidak mendapatkan proporsi secara layak dalam kekuasaan politik. Ini pada akhirnya, akan mendorong Islam Syiah untuk merebut kekuasaan politik sesuai dengan proporsi jumlah mereka. Jika asumsi ini benar, maka Islam Syiah menjadi imbangan kekuatan politik yang besar bagi kelompok muslim Sunni. Sementara di sisi yang lain, kelompok-kelompok kecil yang nasionalis juga akan memperebutkan kekuasaan politik secara proporsional ${ }^{28}$.

Keempat, prakondisi terakhir bagi demokratisasi di Irak adalah faktor-faktor eksternal, yaitu faktor ekonomi, politik, ideologi, dan elemen-elemen lain yang merupakan konteks internasional dari proses yang terjadi di suatu negara. ${ }^{29}$ Saya telah menyinggung sedikit dalam uraian sebelumnya bahwa angin perubahan di negara-negara Islam yang kini sedang bergerak ke sistem demokrasi dapat menjadi lingkungan eksternal yang kondusif bagi proses demokrasi di Irak. Namun sayangnya angin perubahan ini juga diikuti oleh kekerasan akibat konflik yang terus berkepanjangan di kawasan ini. Konflik PalestinaIsrael menjadi lingkungan eksternal yang kurang kondusif bagi pembangunan demokrasi di Irak. Selain itu, kepentingan negara-negara tetangga terhadap Irak seperti Iran, Israel dan Turki menjadikan masa depan demokrasi di Irak semakin sulit diprediksi.

Akhirnya, perjalanan demokrasi di Irak ditentukan oleh keempat faktor di atas, yakni budaya politik, pembangunan ekonomi, struktur sosial masyarakatnya dan lingkungan eksternal. Kemauan kelompokkelompok di Irak untuk mau menerima perbedaaan dan rela berkompetisi secara jujur untuk memperebutkan kekuasaan politik dalam sistem demokrasi sangat menentukan keberhasilan demokratisasi di Irak di masa datang. Namun, ketiadaan pendidikan politik selama rejim Saddam dan rendahnya budaya politik demokratis di wilayah ini sangat mengganggu proses itu sendiri. Akhirnya, pembangunan ekonomi menjadi salah satu variabel penting berikutnya yang menentukan keberhasilan pembangunan demokrasi di Irak pasca invasi.

Lalu di manakah peran AS dalam proses demokratisasi tersebut jika perang ini, menurut George Bush sebagai usaha untuk membebaskan rakyat Irak dan membangun demokrasi di wilayah ini? Apa yang seharusnya dilakukan oleh negara ini dalam mendorong proses tersebut?

Omer Taspinar, Visiting Fellow in Foreign Policy Studies pada the Brookings Institution and Adjunct Professor, Johns Hopkins University, menyatakan bahwa perubahanperubahan yang akan dilakukan AS hendaknya dilakukan secara gradual dan berasal dari rakyat Irak sendiri. Selanjutnya, ia juga menyatakan bahwa model demokrasi Turki hendaknya dijadikan sebagai "kerangka kerja" (framework) dan tidak dijadikan "blueprint." 30

Namun yang menjadi soal adalah apakah benar AS dapat diharapkan untuk mengambil peran yang besar, dan secara jujur membantu negara ini membangun demokrasinya? Suara-suara kritis yang selama ini menentang kebijakan luar negeri AS berkenaan dengan Timur Tengah dan perang melawan terorisme dalam skala yang lebih luas, nampaknya tidak mendukung sama sekali bagi kontribusi AS dalam proses demokrasi ${ }^{31}$. Bahkan sebaliknya, negara ini dianggap sebagai penghalang bagi proses demokratisasi yang sering kali mereka suarakan sendiri. Sebagaimana telah dijelaskan di awal bahwa persoalan perang melawan terorisme dan usaha penjatuhan suatu rejim yang berkuasa yang dilakukan oleh AS tidak ada hubugannya dengan demokrasi. Namun lebih pada apakah negara tersebut akomodatif ataukah tidak 
terhadap kepentingan AS. Oleh karena itu, sebagaimana catatan Chomsky, AS justru seringkali menjadi pendukung setia bagi rejim yang otoriter dan despotis hanya karena negara tersebut lebih akomodatif terhadap kepentingan AS. Salah satu contoh yang dapat diambil dalam hal ini adalah bagaimana peran AS dalam melanggengkan rejim Soeharto yang notabene adalah otoriter dan despotis. Tidak ada yang menyangkal bahwa pada masa Soeharto, rakyat di negara ini tidak pernah menikmati kebebasannya. Beberapa kali pers harus menerima kenyataan pahit karena dibreidel oleh rejim dan bahkan, saat-saat menjelang kejatuhan Soeharto banyak terjadi penculikan terhadap para aktivis demokrasi. Hingga saat ini, beberapa diantara mereka belum ditemukan rimbanya.

Oleh karena itu, mengharapkan peran AS untuk secara jujur turut membangun demokrasi di Irak adalah sangat sulit. Ini karena, sekali lagi bahwa yang menjadi soal adalah bukan persoalan demokratis ataukan tidak rejim tersebut, tetapi lebih pada apakah ia menjadi "pengikut" yang baik bagi AS. Akhirnya, upaya membangun demokrasi di negara ini akan jauh lebih baik jika AS segera meninggalkan Irak sebagaimana pernah dilontarkan oleh Presiden Iran, Mohammad Khatami, dan menyerahkan proses demokratisasi tersebut kepada rakyat Irak sendiri. Namun, jika kita melihat pertimbangan-pertimbangan geopolitis AS dalam melakukan invasi ke Irak, maka hal ini nampaknya menjadi sangat sulit untuk dilakukan karena bagaimanapun AS telah mengeluarkan biaya mahal untuk perang ini. Lebih dari itu, kenyataan menunjukkan bahwa ambisi AS untuk mendirikan sebuah negara Irak baru yang demokratis - tentu sesuai dengan kemauan Washington DC - belum juga terwujud hingga saat ini. Singkatnya, bisa disimpulkan bahwa tampaknya masa depan demokrasi di Irak menjadi semakin suram dan perdamaian di kawasan ini menjadi semakin tidak pasti.

\section{TITIK-TITIK PERDAMAIAN: DARI MANA HARUS BERANGKAT?}

Salah satu pertanyaan yang kini banyak mengemuka di kalangan politikus, pegiat LSM dan ilmuwan politik adalah apakah masa depan Irak dan Timur Tengah akan menjadi lebih baik. Dengan kata lain, apakah janji AS di kawasan ini untuk membawa kemakmuran (prosperity), demokrasi dan perdamaian akan terwujud? Sebagaimana dikutip oleh Radio VOA, Bush berjanji mengenai apa yang ia sebut sebagai "a long term undertaking" untuk membawa perdamaian, kemakmuran, dan demokrasi di wilayah Timur Tengah, dan menurutnya, AS kini sedang membantu rakyat Irak untuk membuat negara mereka menjadi percontohan bagi "keseluruhan kawasan” Timur Tengah.

Namun demikian, bila kita melihat latar belakang serangan AS yang syarat dengan pertimbanganpertimbangan geopolitik sebagaimana telah dipaparkan di atas, maka menjadi sangat sulit untuk mengharapkan niat baik AS tersebut. Bahkan sebaliknya, serangan AS ke Irak tersebut justru dianggap akan merusak perdamaian itu sendiri. Milad Hanna, kolumnis Kristen Ortodoks, dalam tulisannya di harian terkemuka di Mesir, Al-Ahram, menyebutkan bahwa rencana serangan AS terhadap Irak hanya akan menambah koleksi sisi gelap sejarah kemanusiaan dan semakin meneguhkan bahwa perang kembali dihadirkan sebagai bagian dari kehidupan politik ${ }^{32}$. Menurut Milad Hanna, perang sedikit banyak mencederai toleransi, pluralisme dan hubungan baik antar pelbagai bagian masyarakat di Timur Tengah, yang disebut dengan "budaya menerima yang lain." Berkebalikan dengan keyakinan para pemimpin AS bahwa perang ini harus dilakukan untuk memerangi rejim Saddam yang otoriter dan despotis, dalam rangka memerangi terorisme, dan untuk menciptakan perdamaian, Hanna justru mempunyai keyakinan bahwa serangan AS ke Irak akan membalikkan sejarah pada "kebencian pada yang lain."

Realitas di lapangan nampaknya juga mendukung pendapat Milad Hanna tersebut. Serangan AS ke Irak telah mendapat tantangan dari masyarakat dunia, terutama di negara-negara yang mayoritas penduduknya 
Islam. Para penentang perang ini yang terdiri dari para artis, seniman, masyarakat umum, politikus, akademikus, dan para pegiat perdamaian serta pemimpin politik dunia mempunyai keyakinan bahwa perang ini tidak akan membawa perdamaian sebagaimana diharapkan oleh Bush dan Blair. Namun, perang diyakini hanya menimbulkan kesengsaraan dan korban di pihak anak-anak dan wanita. Oleh karena itu, perang tetap diyakini sebagai cara yang paling buruk untuk menyelesaikan masalah. Inilah sebabnya, mengapa sebagian besar opini publik dunia menentang perang yang dicanangkan oleh Bush.

Demonstrasi menentang perang ini berlangsung di sebagian besar dunia termasuk di Inggris, Australia, dan Amerika sendiri. Dengan demikian, tokoh yang oleh Ketua MPR RI disebut sebagai 'Warmonger' atau pemabuk perang ini juga ditentang oleh rakyatnya masing-masing. Di kota-kota seperti Paris, Berlin, dan New York, bahkan di Washington, Sydney, dan Canberra demonstrasi menentang perang tersebut juga berlangsung dengan skala besar ${ }^{33}$. Menurut Amien Rais, hanya Israel sebagai satu-satunya negara yang tidak menentang perang tersebut ${ }^{34}$. Ini sangat masuk akal karena invasi Bush ke Irak sangat menguntungkan Israel karena satu dari sekian banyak musuhnya di Timur Tengah dan mungkin di dunia dilumpuhkan oleh Bush, sebagai sekutu dekatnya.

Namun toh sepahit apapun kenyataan itu, terutama bagi rakyat Irak, perang telah menjadi bagian dari realitas kehidupan itu sendiri. Saddam telah berhasil dipaksa jatuh dari kekuasaan yang digenggamnya selama lebih kurang dua puluh tahun, dan yang tertinggal kini adalah bagaimana merencanakan masa depan yang penuh damai, baik di Irak maupun di Timur Tengah. Namun yang menjadi pertanyaan adalah apakah itu mungkin? Atau, jika perdamaian itu mungkin untuk dicapai, maka perdamaian seperti apa yang hendak diwujudkan dan bagaimana caranya agar ia dapat diwujudkan?

Beberapa pengamat menyarankan agar usaha menciptakan perdamaian di Irak hendaknya dikaitkan dengan usaha pencapaian perdamaian di Timur Tengah $^{35}$. Sementara itu, selama kondisi dalam negeri
Irak masih kacau paska invasi AS, dan pemerintahan baru tidak bisa mampu mengatasinya, maka akan sangat sulit untuk mewujudkan perdamaian di wilayah ini. Meskipun dalam jangka panjang juga tetap masih diragukan apakah faksi-faksi di Irak yang selama ini hidup di bawah tekanan Saddam tidak bertikai untuk memperoleh sumber-sumber kekuasaan. Ini juga menyangkut perubahan sistem pemerintahan yang hendak digunakan di negara itu. Apakah berbentuk republik, atau negara yang mendasarkan pada hukum Islam? Jika negara yang hendak dibentuk berdasarkan Islam, maka Islam yang mana yang akan dijadikan rujukan? Apakah Islam Sunni ataukah Islam Syiah? Jika akhirnya rakyat Irak memutuskan untuk menggunakan hukum Islam sebagai landasan politik pemerintahannya, maka apakah hal ini tidak akan mengundang kekerasan baru dari AS? Pertanyaanpertanyaan ini tentunya mempunyai konsekuensi yang serius di masa yang akan datang, terutama dalam konteks usaha untuk meraih perdamaian di Irak dan Timur Tengah dalam skala yang lebih luas. Akhirnya, perdamaian dan demokrasi, atau lebih utopisnya, kemakmuran tidak semudah yang diungkapkan Bush ketika ia hendak menginvasi Irak dan menjatuhkan rejim Saddam Husein.

Kenneth Katzman, Middle East Specialist at the Congressional Research Service, menyatakan bahwa Islam Syiah menjadi faksi dominan dalam pemerintahan paska invasi dan sebagai hasilnya akan membongkar dominasi dan sekaligus menjadi imbangan berat bagi Partai Baath yang sekuler, kemampuan organisasional mereka dan dalam memobilisasi massa. ${ }^{36}$ Selama ini, kelompok Islam Syiah membiarkan Islam Sunni untuk melawan pendudukan tentara AS dan pada akhirnya akan melemahkan kekuatan AS. Jika hal ini terjadi maka Islam Syiah akan mempunyai kesempatan untuk menuntut haknya. Pernyataan Katzman ini agak bersifat spekulatif. Namun, bahwa peluang Islam Syiah untuk mengambil peran yang besar di Irak adalah masuk akal. Sebagaimana pengalaman banyak negara, dan Indonesia sebagai contohnya. Biasanya kelompokkelompok marginal dan tertindas dalam sistem pemerintahan masa lalu yang otoriter dan despotis 
akan mempunyai peluang yang lebih besar untuk memegang tampuk pemerintahan.

Katzman juga menyatakan bahwa jika Islam Syiah mengambil peran dan kekuasaan di Irak, maka ini membuka peluang bagi Iran untuk mendapatkan pengaruh yang luas dan mendalam di Irak. Namun yang menjadi soal, seandainya benar Islam Syiah mengambil peran dominan dalam pemerintahan Irak di masa mendatang, dan Iran mempunyai pengaruh yang luas di negara ini, apakah Bush akan membiarkan hal tersebut? Menurut Katzman hal ini tetap mungkin karena meskipun Bush sedang "mengincar" Iran sebagai target berikutnya, namun sikap umum di Washington tidak dalam situasi yang menyenangkan untuk melakukan serangan terhadap Iran sebagaimana dilakukan Bush terhadap Saddam.

Namun demikian, di masa datang ini tetap akan menyisakan banyak persoalan di kawasan tersebut. Meskipun angin perubahan telah melanda Iran dalam tahun-tahun belakangan ${ }^{37}$, namun keberadaannya masih menjadi salah satu negara yang sulit mendukung kepentingan-kepentingan AS. Label "axis of evil" yang diberikan Bush terhadap negara Islam ini menjadi tanda kuatnya sentimen Bush terhadap Iran. Selain itu, Israel juga tidak akan begitu saja merelakan Irak berada dalam pengaruh Iran, karena ini akan membahayakan posisi Israel di Timur Tengah. Negaranegara lain di kawasan Timur Tengah juga nampaknya tidak akan menerima begitu saja pengaruh Iran di kawasan itu. Ini berarti bahwa perdamaian di Irak, sama halnya dengan demokrasi, akan tetap menjadi teka-teki.

Kesulitan-kesulitan ini akan menjadi semakin bertambah jika kelompok minoritas Kurdi dimasukkan dalam pembahasan. Selama pemerintahan Saddam Husein, Suku Kurdi yang menempati wilayah Irak Utara banyak mendapatkan tekanan dari rejim Saddam. Selama masa tersebut, suku Kurdi berjuang untuk menentukan nasibnya sendiri, dan selama itu ribuan penduduk Suku Kurdi tewas dalam usaha memperjuangkan otonomi dan kemerdekaan wilayahnya. Dukungan Suku Kurdi terhadap pasukan AS dan Inggris disinyalir juga karena janji yang pernah dilontarkan pejabat Gedung Putih untuk memberi kemerdekaan pada Suku Kurdi pasca Saddam. Sekarang ini, terdapat kurang lebih 100 ribu orang Suku Kurdi bersenjata yang terlatih dalam perang gerilya. Mereka ini, sebagaimana diungkapkan oleh Martin van Bruinessen, tengah berusaha untuk merebut Kirkuk sebagai daerah penghasil minyak terbesar kedua di Irak. Jika ini berhasil, maka akan meninggikan posisi tawar mereka terhadap rejim yang berkuasa.

Persoalan selanjutnya menyangkut posisi Turki dalam mengambil sikap terhadap usaha Suku Kurdi dalam memperjuangkan kemerdekaan wilayahnya. Selama ini, dengan dukungan AS, Turki telah melancarkan state terorism ${ }^{38}$ terhadap penduduk Suku Kurdi yang merupakan seperempat dari penduduk Turki secara keseluruhan. Oleh karena itu, perjuangan Suku Kurdi di Irak Utara untuk mendapatkan kemerdekaan maupun otonomi wilayahnya akan menemui jalan panjang mengingat sikap Turki tentunya tidak akan mendukung usaha-usaha tersebut. Sikap ini besar kemungkinan juga akan didukung oleh AS karena selama puluhan tahun Turki telah menjadi sekutu dekatnya di Timur Tengah selain Israel dan Mesir. Dengan demikian, mengharapkan perdamaian di wilayah Irak hanya dengan menjatuhkan Saddam merupakan sesuatu yang naif. Sebaliknya, sebagaimana ditegaskan oleh Martin van Brueinessen, potensi konflik dan perang di Irak adalah luar biasa besarnya karena tiadanya pemerintahan alternatif yang bisa menggantikan Saddam. Dalam roses perkembangan sekarang, sekalipun AS telah membentuk pemerintahan Irak baru hasil pemilu tidak serta merta melahirkan Irak yang aman dan tenteram. Yang terjadi justru sebaliknya, Irak terperosok ke dalam pusaran perang saudara. Keadaan ini menjadi semakin rumit jika faksi-faksi di Irak pada akhirnya menjadikan AS sebagai common enemy. Kekerasan akan terus berlanjut, dan korban jiwa di pihak anak-anak dan wanita terus berjatuhan. 


\section{PERAN AMERIKA DALAM PROSES PERDAMAIAN TIMUR TENGAH.}

Sejak pemerintahan Jimmy Carter, Timur Tengah telah menjadi "vital interest of the United States". Ini diikuti oleh pernyataan Carter secara terbuka,

An attempt by outside force to gain control on the Persian

Gulf region will be regarded as an assault on the vital interest of the Untied States of America, and such an assault will be repelled by any means necessary, including military force ${ }^{39}$

Namun yang menjadi masalah adalah bahwa anggapan kawasan Teluk Persia sebagai vital interest bagi AS, juga diikuti ketidaknetralan AS dalam konflik Arab-Israel. Sebagaimana pernah diungkapkan oleh Jimmy Carter di Venice tahun 1980, dengan mengatakan secara terbuka bahwa "United States would veto any European attempt to push a UN resolution supporting Palestinian self-determination." 40 Inilah sebenarnya yang membuat proses perdamaian di Timur Tengah sulit dicapai karena ketidaknetralan mediator, dalam hal ini AS. Akibatnya, setiap upaya perdamaian selalu mentah di tengah jalan karena upaya-upaya untuk mencari jalan damai secara adil dan fair selalu dihambat oleh AS sendiri.

Oleh karena itu, jika perdamaian di kawasan ini benar-benar ingin diwujudkan, maka AS harus menjadi "juri" yang adil bagi proses tersebut. Namun nampaknya hal ini sangat sulit dilakukan, karena acapkali AS menggunakan standar ganda berkenaan dengan penyelesaian konflik di Timur Tengah. Akibatnya, dari hari ke hari kelompok-kelompok yang tidak puas terhadap kebijakan AS di Timur Tengah semakin bertambah. Ini pada akhirnya, akan mendorong bentuk-bentuk perlawanan baru di kawasan ini dalam skala yang lebih masif dan terorisme tetap akan menghantui AS dimana saja dan kapan saja, sebagaimana hantu Perang Dingin.

Ini setidaknya pernah diungkapkan oleh Perdana Menteri Singapura, Goh Chok Tong ketika mengunjungi AS beberapa waktu yang lalu. Berkenaan dengan kebijakan AS di Timur Tengah, Goh Chok Tong menyatakan bahwa kebijakan AS di Timur
Tengah membuat banyak warga Muslim di Asia Tenggara semakin tidak nyaman yang berarti memberikan nada anti-AS pada keyakinan agama mereka. Jika hal ini terus berlanjut, maka besar kemungkinan akan memunculkan kelompok militan, dan jika mereka memegang tampuk kekuasaan, maka akan membuka masalah strategis global. Selain itu, Goh Chok Tong juga menyatakan bahwa AS harus memegang peran utama dalam mewujudkan perdamaian di Timur Tengah, sebagai perimbangan bagi agresi yang telah dilancarkan demi opini internasional ${ }^{41}$. Lebih lanjut ia mendesak agar AS menggunakan kekuasaannya yang sangat besar tersebut untuk membawa perdamaian ke kawasan Timur Tengah dan kegagalan AS untuk melakukan usaha membawa perdamaian di Timur Tengah akan membangkitkan kelompok garis keras. Ia juga mendesak AS agar perang terhadap terorisme atau ketakutan pada kekuasaan AS diakhiri segera karena hal ini meresahkan banyak warga muslim di dunia.

Ungkapan Goh Chok Tong ini mengindikaskan bahwa proses perdamaian di Timur Tengah akan sangat ditentukan oleh sikap AS terhadap Israel dan negara-negara Arab. Dengan kata lain, sikap yang adil dari para pemimpin AS dalam menyikapi konflik di Timur Tengah akan sangat menentukan prospek perdamaian di kawasan ini. Pasca tragedi WTC, AS sangat getol dalam memerangi negara-negara yang dituduh mengembangkan senjata pemusnah massal, setidaknya setiap aksi AS dalam "menghukum” negaranegara Timur Tengah adalah karena pengembangan senjata pemusnah massal dan dalam rangka memerangi terorisme, meskipun pada dasarnya hal ini hanya menyangkut kemauan negara tersebut untuk mau atau tidak mengakomodasi kepentingan AS. Kasus Irak dan Afghanistan menjadi contoh untuk ini. Namun, hal yang sama tidak dilakukan terhadap Israel. Bahkan sebaliknya, AS memberi bantuan militer kepada Israel dan pengembangan industri perdagangannya. Tidak ada satupun dari pejabat Gedung Putih yang mengecam pembantaian-pembantaian yang dilakukan oleh Israel terhadap orang-orang Palestina, dan tidak ada satupun dari mereka yang mengancam Israel karena 
pengembangan senjata pemusnah massal. Ini hanya dilakukan kepada negara-negara Arab yang tidak sepaham dengan AS.

Kondisi ini tentunya akan menjadi semakin parah jika kebijakan bantuan militer kepada negara-negara sekutu AS di Timur Tengah terus dilanjutkan, karena akan mendorong perlombaan persenjataan dalam skala yang lebih luas di kawasan. Selain Israel, AS telah memberikan bantuan militer yang cukup besar kepada Turki dan negara-negara Timur Tengah lainnya. Oleh karena itu, kekerasan bersenjata yang terus menerus berlangsung di kawasan Timur Tengah pada dasarnya adalah tanggung jawab AS dan negara-negara Eropa. Oleh karena negara-negara inilah, ditambah Rusia, yang menjadi pemasok utama perlengkapan militer. Sebagai contoh, pada masa kejayaan Saddam, AS dan Inggris adalah negara yang paling berperan besar dalam pengembangan senjata pemusnah massal Irak, terutama selama Perang Irak-Iran. Sebagai sekutu dekatnya, Saddam pernah menikmati bantuan militer dalam jumlah besar dari AS dan Inggris. Namun setelah Saddam tidak lagi akomodatif terhadap kepentingan-kepentingan AS di Timur Tengah, terutama karena sikapnya terhadap Israel, negara ini akhirnya diluluhlantakan oleh angkatan perang AS dan Inggris. Sementara itu, sebagaimana disinggung di awal, bantuan-bantuan militer AS di Turki digunakan untuk melakukan state terorism terhadap masyarakat sipil, sedangkan bantuan militer AS untuk Israel digunakan untuk melakukan teror dan pengusiran terhadap orang-orang Palestina.

Oleh karena itu, untuk menghentikan kekerasan dan konflik bersenjata di kawasan ini, maka AS harus menghentikan semua bentuk bantuan militer kepada negara-negara sekutunya di Timur Tengah agar tidak terjadi perlombaan senjata, dan mencegah terjadinya state terorism. Namun hal ini nampaknya akan sangat sulit dilakukan karena penjualan peralatan militer di negara-negara Timur Tengah disinyalir sebagai kompensasi terhadap uang yang dibayarkan AS untuk pembelian minyak dari negara-negara di kawasan ini. Dengan demikian, perdamaian yang dicitakan-citakan tetap menjadi sebuah impian.

\section{PENYELESAIAN MASALAH PALESTINA-IS- RAEL}

Banyak pengamat menilai bahwa persoalan Palestina-Israel menjadi conditio sine qua non bagi sengketa menyeluruh Arab-Israel ${ }^{42}$. Ini karena sebenarnya konflik Arab-Israel bermula pada konflik Palestina-Israel, konflik inilah yang berlangsung secara abadi bahkan tumbuh anggapan bahwa selama Israel belum memberikan otoritas dan pengakuan penuh kepada Palestina, dan dataran Golan diserahkan kepada Syria, serta Israel menarik pasukannya dari Libanon Selatan, maka Timur Tengah tidak akan pernah mengalami masa perdamaian ${ }^{43}$.

Konflik Arab-Israel ini bermula ketika Theodor Herzl (1960-1904) menulis mengenai Zionisme dengan judul "Der Judenstaat" yang artinya orang Yahudi. Tulisan ini telah melahirkan gerakan Zionisme yang pada dasarnya berintikan bahwa Bangsa Yahudilah yang paling unggul dibandingkan dengan bangsa-bangsa lain di dunia, dan Yahudi dituntut untuk mendirikan negara sendiri lepas dari $\mathrm{Arab}^{44}$. Untuk mewujudkan usaha membangun negara tersebut, Israel mengusir orang-orang Palestina dari tanah kelahiran, dan sejak itu konflik yang meluas antara Israel dan Arab dimulai.

Berbagai perundingan yang dilakukan untuk menyelesaikan sengketa Palestina Israel tidak pernah berhasil diimplementasikan, akibat kekerasan yang dilakukan Israel dan perlawanan-perlawanan yang dilakukan oleh Hammas. Pelanggaran-pelanggaran terhadap perjanjian ini membuat masa depan perdamaian di kawasan ini menjadi sulit diprediksi.

Sementara itu, nasib Peta Jalan (Road Map) damai yang diusulkan oleh AS nampaknya juga akan mengalami kegagalan dalam implementasinya. Sebuah analisis yang dimuat dalam www.arabfreevoice.com, dengan judul "What Happened to the Peace Process," setidaknya mengungkapkan hal ini. Menurut analisis tersebut, peta jalan damai akan dapat diimplementasikan dengan baik jika Washington menyatakan harus dilaksanakan dan tidak ada lagi hal yang perlu dinegosiasikan. Namun, sekali lagi bahwa sikap AS yang sangat lunak terhadap Israel membuat 
implementasi Road Map ini menjadi sulit. Analisis ini mengatakan bahwa meskipun Perdana Menteri Sharon menerima konsep Road Map, tetapi ia tidak mempunyai maksud untuk memberikan negara Palestina dalam arti yang sesungguhnya sebagaimana dimaksudkan oleh Peta Jalan tersebut. Sementara itu, Chomsky menyatakan bahwa lawatan yang dilakukan oleh Colin Powel ${ }^{45}$ ke Timur Tengah tidak ditujukan untuk menyukseskan Peta Jalan sebagaimana nampaknya, namun lebih ditujukan pada usaha untuk menggalang dukungan AS dalam rangka melakukan invasi ke Irak. Ini berarti bahwa setelah AS berhasil menggulingkan rejim Saddam Husein dan Irak sudah berada dalam kontrol AS, maka implementasi Peta Jalan tersebut menjadi sangat tergantung pada Sharon. Padahal menurut analisis tadi, permainan yang kini tengah disusun Sharon menyangkut peta jalan damai tadi adalah penundaan yang tiada habis-habisnya sehingga ia dapat melewati empat tahun pemerintahannya tanpa perubahan kebijakan yang mendasar, sementara di sisi yang lain tetap mendapatkan dukungan dari Washington. Sharon dapat saja menghindari implementasi peta jalan ini dengan menyatakan bahwa harus ada penghentian kekerasan secara absolut dan pendirian sebuah negara demokrasi di Palestina, sebagai prakondisi untuk gerakan-gerakan Israel selanjutnya. Kondisi ini tentu saja sulit dipenuhi mengingat gerakan-gerakan kelompok radikal hingga kini masih terus berlangsung di tempat-tempat pendudukan Israel, dan tekanantekanan terhadap otoritas Palestina terus dilakukan guna memerangi kelompok radikal. Sementara usaha membangun negara demokrasi bukanlah pekerjaan yang mudah. Akhirnya, berdasarkan tuntutan-tututan Sharon tersebut, pelaksanaan peta jalan damai menjadi sangat sulit. Kemungkinan yang lain, sebagaimana dikemukakan oleh analisis tersebut, bahwa Sharon dapat saja menerima pendirian negara Palestina merdeka dengan catatan negara merdeka itu didirikan dalam wilayah yang mencakup 40-50 persen dari wilayah West Bank dan Gaza. Jika hal ini terjadi, maka Israel akan menempati wilayah sebesar 88-90 persen, sedangkan Palestina hanya akan menempati kurang dari
10 persen dari wilayah Palestina. Ini tentu saja tidak akan dapat diterima oleh Palestina, dan sebagai akibatnya, konflik antara Israel dan Palestina akan terus berlangsung.

Dengan demikian, keberhasilan penyelesaian masalah Palestina Israel akan sangat ditentukan oleh sikap AS itu sendiri untuk secara sungguh-sungguh mencari penyelesaian secara adil bagi kedua belah pihak. Namun, sebagaimana telah dikemukakan di awal bahwa sikap AS yang sangat berpihak Israel menjadi hambatan paling besar bagi proses perdamaian Palestina dan Israel. Ini dapat dilihat dari pandangan Bush menyangkut perlawanan-perlawanan yang dilakukan oleh pejuang Palestina terhadap tentara Israel. Bush menganggap bahwa bom-bom bunuh diri adalah sebagai tindakan terorisme, dan karenanya selalu mengancam usaha perdamaian yang sedang diperjuangkan, sementara tindakan-tindakan Israel adalah sebagai reaksi terhadap serangan-serangan tersebut. Sebagaimana dikemukakan oleh Sekretaris Pers,

"Presiden yakin bahwa siapa pun yang memasang bahan peledak pada dirinya untuk bunuh diri, dan sebagai akibatnya membunuh orang yang tidak berdosa adalah seorang teroris, terlepas dari aksi atau motif yang dikatakan mendasari tindakannya; hal ini adalah terorisme. Dan inilah yang menyulitkan persoalan di kawasan tersebut. Hal inilah yang menjurus kepada kekerasan berikutnya dan yang mengakibatkan tindakan Israel, ${ }^{46}$

Pandangan seperti inilah yang membuat umat Islam merasa dipojokkan dalam konteks penyelesaian Israel Palestina, dan Timur Tengah pada umumnya. Label terorisme selalu dilekatkan pada pejuang Palestina, sementara pembunuhan-pembunuhan yang dilakukan terhadap rakyat Palestina dianggap sebagai upaya memerangi terorisme. Akibatnya, terjadi gerakan terorisme dalam skala yang lebih luas yang mengancam semua kepentingan AS di beberapa kawasan, dan serangan terhadap WTC pada tanggal 11 September menjadi puncak dari aksi terorisme tersebut. 


\section{KESIMPULAN}

Invasi AS ke Irak telah menimbulkan sejumlah diskusi di kalangan para pengamat politik internasional. Diskusi tersebut meliputi: aspek legalitas dari invasi yang dilakukan AS; motivasi di balik serangan AS terhadap Irak; masa depan demokrasi dan perdamaian di kawasan tersebut. Bagi AS, invasi ke Irak ini adalah penting dalam rangka memerangi terorisme dan menghancurkan senjata pemusnah massal, membebaskan rakyat Irak dari rejim Saddam dan mendorong terciptanya demokrasi di negara tersebut. Namun, dalam kenyataannya invasi AS ke Irak tidak dapat dilepaskan dari pertimbanganpertimbangan geopolitik, terutama dalam konteks mengamankan kepentingan minyak dan melindungi sekutu dekatnya, yakni Israel.

Kuatnya pertimbangan geopolitik dalam melakukan invasi ke Irak sangat mempengaruhi peran AS dalam mendorong demokrasi dan perdamaian di Irak. Suarasuara kritis yang selama ini mengemuka, mengatakan bahwa invasi yang dilakukan AS di negara-negara otoriter tidak ada hubungannya dengan pelaksanaan demokrasi di negara tersebut. Namun lebih pada apakah negara tersebut adaptif terhadap kepentingankepentingan AS ataukah tidak. Kontribusi AS bagi demokratisasi di negara tersebut juga kecil. Oleh karena itu, masa depan demokrasi di Irak menjadi tanda tanya besar. Pertama, potensi konflik antar faksi di Irak sangatlah besar. Islam Syiah mempunyai peluang besar untuk berkuasa, dan menyaingi kelompok Islam Sunni. Jika hal ini terjadi, maka besar kemungkinan negara-negara lain yang mempunyai kepentingan terhadap Irak seperti Turki, Iran dan tentu saja Israel akan melakukan intervensi. Kedua, kondisi sosial ekonomi yang carut marut selama embargo yang dilakukan PBB pasca invasi Irak ke Kuwait. Embargo yang telah berlangsung selama kurang lebih sepuluh tahun ini telah membuat kehidupan rakyat berada dalam situasi yang mengenaskan. Penduduk kekurangan bahan makanan, obat-obatan, pasokan listrik dan air. Sementara sebagian besar anak-anak kekurangan gizi. Ditambah dengan rendahnya budaya politik yang mendukung demokrasi akibat lamanya rejim yang otoriter berkuasa membuat pelaksanaan demokrasi di Irak menjadi semakin sulit dalam Ini pada akhirnya akan sangat menentukan stabilitas di Timur Tengah secara keseluruhan. Ketiga, peran AS sendiri dalam mendorong proses demokratisasi. AS dapat berperan menjadi fasilitator yang baik dalam proses demokratisasi di Irak, namun juga sebaliknya, ia bisa saja menjadi penghambat bagi demokratisasi itu sendiri. Ini karena, sekali lagi, bukan masalah demokratis dan tidaknya rejim yang berkuasa, namun lebih pada kemampuan rejim tersebut dalam mendukung kepentingan AS. Meskipun suatu rejim bersifat demokratis besar kemungkinan akan tetap dihancurkan oleh AS jika negara tersebut menghambat kepentingan-kepentingan AS. Sementara negara-negara yang loyal terhadap AS akan terus mendapatkan bantuan, meskipun rejim di negara itu otoriter dan despotis.

Prospek perdamaian di Irak dan kawasan Timur Tengah masih menyisakan tanda tanya. Pertama, menyangkut konflik di Irak sendiri. Tidak ada jaminan bahwa faksi-faksi yang kini berada di Irak tidak melakukan perebutan kekuasaan terhadap pemerintahan baru Irak dengan menggunakan kekerasan bersenjata. Jika hal ini terjadi, maka akan sangat berpengaruh pada stabilitas di Timur Tengah. Kedua, penyelesaian masalah Palestina-Israel belum jelas hingga saat ini. Padahal penyelesaian sengketa Palestina-Israel merupakan conditio sine qua non bagi pembahasan perdamaian di Timur Tengah menyeluruh. Dalam prakteknya, Road Map (jalan damai) yang disponsori AS dihambat oleh Israel sendiri. Sementara ketidaktegasan AS dalam menentukan sikap terhadap Israel sangat menentukan penyelesaian sengketa Israel- Palestina, dan dengan demikian perdamaian di Timur Tengah. Namun, sikap yang selama ini ditunjukkan AS sangat akomodatif terhadap Israel dan defensif terhadaap pejuang-pejuang Palestina. Selama Bush Jr mempunyai keyakinan bahwa perusak perdamaian adalah karena bom-bom bunuh diri yang dilakukan pejuang Hammas dan karenanya dianggap sebagai terorisme, sementara 
pembunuhan-pembunuhan yang dilakukan Israel terhadap warga Palestina sebagai reaksi terhadap tindakan-tindakan tersebut, dan bukan sebaliknya, maka masa depan penyelesaian Israel Palestina masih akan tetap suram.

Akhirnya, kegagalan penyelesaian konflik Israel Palestina dan dengan demikian, konflik Arab Israel ditambah dengan sikap AS yang sangat akomodatif terhadap kepentingan Israel memunculkan kekerasan yang semakin meluas. Ketidakpuasan kelompokkelompok Islam garis keras atas sikap AS di Timur Tengah, akan terus melancarkan perlawanan terhadap kepentingan AS di mana-mana, dan terorisme akan tetap menjadi hantu yang menakutkan di abad ini.

\section{CATATAN AKHIR}

Tempo Interaktif, 20 Maret 2003

2 Kutipan ini diambil dari tulisan Raha Rafii, "Iran Influence in Irak Debated Congress," dalam http://www.iraniantrade.org/update/ news.asp? $1 \mathrm{~d}=2673$

3 Noam Chomsky lebih sering menggunakan kata ini dibandingkan invasi dalam menggambarkan aksi-aksi militer AS ke negara-negara lain yang tidak adaptif terhadap kepentingan AS. Lihat Noam Chomsky (2003), Power and Teror: Perbincangan Pasca Tragedi WTC 11 September 2001 (Yogyakarta: Ikon Teralitera).

4 Heribertus Jaka Triyana (2003), "Stabilitas Irak Pasca Konflik," artikel di-download dari http://www.apcml.org/documents/PaperJaka.rtf

5 Alasan Presiden Bush menginvasi Irak karena kepemilikan senjata pemusnah massal hingga saat ini masih menimbulkan perdebatan di kalangan para pengamat, dan dalam negeri juga masih mengundang kontroversi. Ini karena program senjata pemusnah massal yang dituduhkan Amerika kepada Irak belum dapat dibuktikan. Kritik ini ditulis oleh Patrick Martin, "US Government Lied about Iraki Weapon to Justify War," http://www.wsws.org/ articles/2003, 23 Maret 2003.

6 Tempo Interaktif, 4 Apr 2003 19:19:52 WIB

7 M. Solihat (203), Amerika dan Pilihan "Jalan Perang," dalam http:// www. cides.or.id/politik/pk0013033.asp

8 Lihat tulisan Noam Chomsky and Michael Albert, "Gulf War Pullout," ZMagazine download dari http://www.zmag.org/ chomsky/index.cfm.

9 Lihat Hasnan Habib (1994), "Amerika dan Stabilitas Dunia," dalam Hasnan Habib (1997), Kapita Selekta: Strategi dan Hubungan Internasional (Jakarta: CSIS), hal. 514.

10 Ibid

11 Kepentingan nasional Amerika telah digariskan dalam Preambule dari konstitusi AS, yakni: mengupayakan kesatuan dan persatuan yang lebih sempurna; keadilan; ketenangan dan kedamaian domestik; pertahanan yang memadai; kesejahteraan ekonomi; dan berkah yang diberikan oleh kebebasan, tidak hanya oleh generasi sekarang, tetapi juga untuk generasi yang akan datang. Nilai-nilai dasar itu hanya bisa direalisasikan jika negara dan bangsa dapat eksis berkesinambungan dalam lingkungan yang aman dan damai, sehingga kemerdekaan, integritas wilayah, lembaga-lembaga yang fundamental, dan suatu tingkat kehidupan politik, ekonomi, sosial, dan kemampuan militer yang tinggi dapat terjamin (John M. Collins, 1973, dalam Hasnan Habib, ibid., hal. 513).

12 William K. Tabb (2003), Tabir Politik Globalisasi (Yogyakarta: Lafadl), hal. xiv.

13 Dalam kasus penggulingan Rejim Taliban misalnya, Profesor K. Tabb memberi catatan bahwa perang AS melawan terorisme telah menutup skandal Enron. Penggunaan kekuatan militer telah mengaburkan kaitan antara perusahaan-perusahaan energi AS yang mendukung dan didukung oleh pemerintahan Bush dengan aktivitas mereka di wilayah-wilayah operasi militer Amerika. Oleh karena itu, tuntutan untuk menggulingkan Taliban adalah tuntutan mereka yang telah berinvestasi dalam skala besar di wilayah-wilayah tersebut. Perusahaan-perusahaan yang dimaksud adalah Enron, Exxon Mobil, dan Halliburton (merupakan perusahaan dari Wakil Presiden Dick. Cheney). Perusahaan-perusahaan ini juga mengambil peran penting dalam restrukturisasi Irak pasca invasi.

14 Ibid, hal. xv.

15 Pikiran Rakyat, Sabtu 17 Mei 2003.

16 Dalam konteks Indonesia, William K. Tabb menyatakan bahwa banyak orang menghujat Rezim Orde Baru atas pelanggaranpelanggaran hak asasi yang mereka lakukan, namun tidak banyak dari suara-suara itu yang mengkritik Amerika karena telah berperan besar dalam melanggengkan rezim Orde Baru yang otoriter dan despotis. Lihat, William K. Tabb (2003), Tabir Politik Globalisasi, (Yogyakarta: Lafadl).

17 Lihat tulisan Pramono U. Thantowi, dalam Harian Kompas, "Invasi ke Irak dan Demokratisasi Timur Tengah," diambil dari http:// www.kompas.com/kompas-cetak/0304/14/opini/254217.htm.

18 Tulisan menyangkut hal ini dapat dilihat dalam http://www.cato.org/ people/basham.html., Patrick Basham (2003), "A Democratic Irak? Don't Hold Your Breath."

19 John Markoff (2003), Gelombang Demokrasi Dunia: Gerakan Sosial dan Perubahan, penyunting Heru Nugroho (Yogyakarta: Pustaka Pelajar bekerjasama dengan Center for Critical Social Studies (CCSS)), hal. 19.

20 Georg Sorensen (2003), Demokrasi dan Demokratisasi: Proses dan Prospek dalam Sebuah Dunia yang Sedang Berubah, (Yogyakarta: Pustaka Pelajar with CCSS), hal. 45.

21 Dirgo D. Purbo, (2003), "Haruskan AS Menyerang Irak," unknown. 22 ibid

23 Carl Cohen (1971) dikutip dari Georg Sorensen (2003), Demokrasi dan Demokratisasi: Proses dan Prospek dalam Sebuah Dunia yang Sedang Berubah, (Yogyakarta: Pustaka Pelajar with CCSS), hal. 16.

24 Nick Beams (2003), "The Polical Economy of American Militerism," dalam http://www.wsws.org/articles/2003/jul2003/nb1-j10.shtml 11 Juli 2003.

25 Proyek perusahaan-perusahaan AS inilah yang menjadi sorotan para pengamat menyangkut kuatnya motif ekonomi AS menyerang Irak.

26 Kedaulatan Rakyat, 11 Agustus 2003.

27 Triyana, op. cit.,

28 Martin van Brueinessen (2003), dikutip dari "Malapetaka Menanti Irak," dalam http://www.rnw.nl/ranesi/html/malapetaka irak.html 
29 Sorensen, op. cit., hal. 45

30 Raha Rafii, op. cit.

31 Chomsky, misalnya, dan William K. Tabb yang pendapatnya telah dikutip di awal adalah orang-orang yang cukup pesimis terhadap kontribusi AS bagi pembangunan demokrasi di dunia.

32 Zuhairi Misrawi (2003, "Oase Perdamaian di Tengah Ambisi Perang," Kompas, Kamis 27 Februari 2003

33 Amien Rais (2003), "Sang Penghancur Peradaban," download dari www.m-amienrais. com. Kolom, Senin, 31 Maret 2003.

34 Lihat juga tulisan Bar On, "What Happened to the Peace Process," dalam www.fmep.org

35 Abdur Rahman Wahid, "Perdamaian Terwujud di Timur Tengah," download from http://www.gusdur.net/ detail.asp? catName $=$ Kolom\&contentOID $=1046$.

36 Raha Rafii, op. cit.

37 Dalam beberapa tahun belakangan angin demokrasi telah mulai berhembus di negara yang sebagian besar penduduknya menganut Islam Syiah ini. Dalam sebuah pidato di depan massa di Karavan, Presiden Iran Khatami pun menyerukan agar pembentukan sistem yang demokratis di Irak dilakukan oleh rakyat Irak sendiri dengan dukungan dari rakyat dunia, termasuk negara-negara di Timur Tengah. Menurut Khatami, negara-negara Timor Tengah seharusnya membangun solidaritas dan tidak mengizinkan negara lain mengintervensi kawasan ini. Sebagaimana diungkapkan Khatami, "Kita seharusnya mempersiapkan diri untuk pendirian pembentukan sistem demokrasi dan pemerintahan di Irak, yang akan menciptakan perdamaian di kawasan ini." la juga menyatakan bahwa PBB, yang saat ini sedang dicemooh karena ketidakberdayaannya menghadap aksi sepihak AS atas Irak, untuk bertindak lebih tegas sesuai opini dunia dan mempersiapkan rakyat Irak untuk memutuskan nasibnya sendiri. Pernyataan Khatami ini dilansir oleh detik kom. http:// www.detik.com/peristiwa/2003/04/13/20030413-015547.shtml Istilah ini dikemukakan oleh seorang sosiolog Turki, Ismail Besikci dalam buku yang ia tulis State Teror in the Middle East. Akibat tulisan ini, Besikci mendekam di penjara selama lima tahun. Lihat Noam Chomsky, Power and Teror, op. cit, hal. 60.

39 Purbo.op. cit.

40 ibid.

41 Pikiran Rakyat, Sabtu 17 Mei 2003.

42 Hasnan Habib, op. cit., hal. 434

43 Kirdi Dipoyudo (1977), Timur Tengah dalam Pergolakan (Jakarta: Yayasan Proklamasi CSIS), hal. 3.

44 Riza Sihbudi (1991), Bara Timur Tengah, (Bandung: Mizan), hal. 45

45 Chomsky, op. cit.

46 Siaran pers Kedutaan Besar AS, 4 April 2002, http:// usembassy.state.gov/jakarta/wwwhtt04.html

\section{BIBILIOGRAFI}

\section{BUKU}

Chomsky, Noam (2003), Power and Teror: Perbincangan Pasca Tragedi WTC 11 September 2001 (Yogyakarta: Ikon Teralitera).

Dipoyudo, Kirdi (1977), Timur Tengah dalam Pergolakan (Jakarta: Yayasan Proklamasi CSIS).

Habib, Hasnan (1994), "Amerika dan Stabilitas Dunia," dalam Hasnan Habib (1997), Kapita Selekta: Strategi dan Hubungan Internasional
(Jakarta: CSIS)

Markoff, John (2003), Gelombang Demokrasi Dunia: Gerakan Sosial dan Perubahan, penyunting Heru Nugroho (Yogyakarta: Pustaka Pelajar bekerjasama dengan Center for Critical Social Studies (CCSS)). Tabb, William K. (2003), Tabir Politik Globalisasi (Yogyakarta: Lafadl). Sorensen, Georg (2003), Demokrasi dan Demokratisasi: Proses dan Prospek dalam Sebuah Dunia yang Sedang Berubah, (Yogyakarta: Pustaka Pelajar with CCSS).

Sihbudi, Riza (1991), Bara Timur Tengah, (Bandung: Mizan).

\section{Artikel dari website}

Bar On, "What Happened to the Peace Process," dalam www.fmep.org Basham, Patrick (2003), "A Democratic Irak? Don't Hold Your Breath," download dari http://www.cato.org/people/basham.html.

Beams, Nick (2003), "The Polical Economy of American Militerism," dalam http://www.wsws.org/articles/2003/jul2003/nb1-j10.shtml, 11Juli 2003.

Chomsky, Noam and Michael Albert (1991), "Gulf War Pullout," Z Magazine download dari http://www.zmag.org/chomsky/ index.cfm.

Patrick Martin, "US Government Lied about Iraki Weapon to Justify War," http://www.wsws.org/articles/2003, 23 Maret 2003.

Purbo, Dirgo D, (2003), "Haruskan AS Menyerang Irak," unknown.

Rafii, Raha (2003), "Iran Influence in Irak Debated Congress," dalam http://www.iraniantrade.org/update/news.asp?ld=2673

Rais, Amien (2003), "Sang Penghancur Peradaban," download dari www.m-amienrais. com. Kolom, Senin, 31 Maret 2003.

Solihat, M. (203), Amerika dan Pilihan "Jalan Perang," dalam http:// www. cides.or.id/politik/pk0013033.asp

Triyana, Heribertus Jaka (2003), "Stabilitas Irak Pasca Konflik," artikel didownload dari http://www.apcml.org/documents/PaperJaka.rtf

Wahid, Abdur Rahman (2003) "Perdamaian Terwujud di Timur Tengah?" download from http://www.gusdur.net/ detail.asp?catName=Kolom\&contentOID $=1046$

\section{Surat kabar}

Kedaulatan Rakyat, 11 Agustus 2003

Pikiran Rakyat, Sabtu 17 Mei 2003.

\section{Artikel Surat kabar}

Misrawi, Zuhairi (2003, "Oase Perdamaian di Tengah Ambisi Perang," Kompas, Kamis 27 Februari 2003.

Thantowi, Pramono U. (2003) "Invasi ke Irak dan Demokratisasi Timur Tengah," Kompas, 3 April 2003

Agan, Polykarpus Ulin "Demokrasi Membutuhkan Inkulturasi, " Kompas, 12 Mei 2003

\section{Sumber lain}

Tempo Interaktif, 20 Maret 2003

Tempo Interaktif, 4 Apr 2003

http://www.detik.com/peristiwa/2003/04/13/20030413-015547.shtml http://www.iraniantrade.org/update/news.asp?ld=2673

http://www.rnw.nl/ranesi/html/malapetaka_irak.html http://www.rnw.nl/ranesi/html/kekacauan besar.html http://www.rnw.nl/ranesi/html/powell_ke_timur_tengah.html http://www.cato.org/dailys/03-31-03.html 